\title{
The logical foundations of constitutional democracy between legal positivism and natural law theory
}

\author{
Hartmut Kliemt ${ }^{1}$ (D) \\ Received: 31 May 2019 / Accepted: 13 February 2021 \\ (c) The Author(s) 2021
}

\begin{abstract}
Rejecting all knowledge claims concerning right and wrong in matters practical James Buchanan concurred with legal positivism that invalid law cannot be identified by its substantive content but only by an inherited defect in its factual creation. Beyond correct creation Buchanan proposed as a quasi-natural law constraint that unanimity in the shadow of individual veto power must at least be conceivable if a norm is to be law. The emerging hybrid conception of constitutional law is symptomatic for Buchanan's never-ending but ultimately futile efforts to incorporate Kantian ideals of interpersonal respect into constitutional economics without imposing them as personal values.
\end{abstract}

Keywords Buchanan $\cdot$ Kant $\cdot$ Kelsen $\cdot$ Rule of law $\cdot$ Legal positivism $\cdot$ Natural law

\section{Introduction and overview}

According to the basic ("procedural") norm of Buchanan's andTullock's seminal Calculus of Consent, (1962/1999, vol. 3), ${ }^{1}$ any substantive normative content can become valid law provided that the "democratic sovereign" ("could conceivably have") accepted it with "democratic unanimity in the shadow of individual veto power". That any content can become law if it is identified as law by a factually prevailing "rule of recognition" (Hart, 1961 ) is the central legal positivist tenet while the normative proviso of "democratic unanimity in the shadow of individual veto power" goes beyond a positivist rule of recognition in that it rules out content and is in this sense functionally equivalent to substantive normative requirements of natural law theories. ${ }^{2}$

\footnotetext{
1 All references to Buchanan's writing will be to the Liberty Fund edition of "The Collected Works of James Buchanan" (1999 ff.) with additional specifics like volume no. and in case of books original publication date.

${ }^{2}$ Beyond legal philosophy this is another expression of the tension in Buchanan's work between, on the one hand, a morally relativist conception of justifying value judgments and, on the other, his deeply felt Kantian ideals of interpersonal respect; see for additional background in relation to the Calculus (Kliemt, 1994).
}

Hartmut Kliemt

Hartmut.kliemt@t-online.de

1 Behavioral and Institutional Economics, University of Giessen, Giessen, Germany 
In what follows I shall, first, identify in Buchanan's approach to constitutional law mirror images of crucial elements of Hans Kelsen's "pure theory of law" (see Sect. 2). ${ }^{3}$ Next, I will sketch why Buchanan must fail in aligning his own broadly Hartian positivism and ethical relativism with his conception of the authority of constitutional democratic procedures (see Sect. 3). As a final observation I will indicate why I regard Buchanan's as a variant of philosophical contractarianism that is superior to most of its competitors but also why I remain ultimately unconvinced by contractarianism (see Sect. 4). - Since Buchanan typically launches his own theoretical assaults on foundational issues from Hobbesian ideas let me start from there, too. ${ }^{4}$

\section{From Hobbes to Buchanan}

Hobbes characterized the "state of nature" by the absence of obligations to commit or to omit any act. ${ }^{5}$ Since for him all obligations concerning overt action are ,,artificially “ created through factual conventions (positive social rules and positive law) nothing is ruled out as normatively illegitimate a priori.

\subsection{Hobbesian natural law}

Hobbes refers to the absence of all "positive" obligations in state of nature as the ,natural right" to everything. Since there are no (positive) obligations corresponding to it this ,right to everything “ bestows no (institutional) legal powers on actors. ${ }^{6}$ In line with this in Leviathan the term ,law of nature " refers to technological recipes (advice) of how to get one's way in pursuit of contingently "given" ends. These recipes are expressive of empirical knowledge to the extent that the achievement of given aims, ends or values can be furthered by bringing about the antecedent conditions of the underlying factual law-like regularities. ${ }^{7}$

\footnotetext{
${ }^{3}$ Kelsen's pure theory of law (Kelsen, 1934/2000) is not only a paradigm example of legal positivism. Its efforts to grapple with "normativity" in quasi-Kantian ways also show striking parallels to problems with which Buchanan tries to come to terms. Reconstructing unavoidable ("quasi-transcendental") pre-suppositions of treating law as valid and binding is a problem for which Kelsen offers his "Grundnorm" construction while Buchanan relies on his "relatively absolute absolutes". For a legal positivist approach that avoids many of the problems of normativity, see Hart (1961); a sophisticated defense that takes into account criticisms of Hart is provided in (Coleman 1985) and a short reliable overview in (Green 2018).

${ }^{4}$ See for a distinctively Hobbesian starting point e.g. Buchanan's work "the limits of liberty", (1975/2000, vol. 7).

${ }^{5}$ It is a state of affairs free of plausible obligations to omit any act that might on the whole be advantageous for an actor; a conceptual construction whose implications Kant in his „,Metaphysics of Morals "\$ 42 (not of „Grundlegung “!) fully understood (Kant 1991). The ,,duty “ to hope for a better state to which Hobbes alludes as operative ,in foro interno “ only, is put into the foreground by Kant though acknowledging the restrictions of duty in foro externo (the realm of overt action).

${ }^{6}$ There is no addressee in this world to whom individuals could turn in support of their "right". "The demand for a right is no more that right than hunger is bread" (Bentham 1843); see the preceding footnote, too.

${ }^{7}$ Hobbes' conception of power and the legitimacy of power-seeking in Leviathan, § 10, first sentences states ,THE 'POWER of a man,' to take it universally, is his present means, to obtain some future apparent good "(Hobbes, 1651/1968)... Taking the term power as ,any potential” and the term ,apparent “ as seriously as Spinoza (Spinoza, 1670/1951), chap. 16 did, we can infer that even the obligation to preserve one's own life is not a natural one. There is only a natural tendency in this subjectivist reading. The objectivist reading that includes obligations to self is certainly possible and leads to a somewhat more medieval inter-
} 
Restricting the powers of reason to instrumental rationality Buchanan accepts that reason cannot tell us which substantive ends should be pursued. ${ }^{8}$ Accusing those who claim objective knowledge of ends to "play at being God" (Buchanan, 1975/2000, p. 4) ${ }^{9}$ he insists that the democratic body politic is endowed with the ultimate normative authority to set ends and to enact rules in fundamental constitutional politics. ${ }^{10}$ Having ultimate authority the community of all members of a polity is substantively unconstrained while procedurally constrained by the unanimity proviso. ${ }^{11}$

According to the preceding reconstruction, the "democratic body politic" of the calculus is sovereign in the classical Hobbesian sense of commanding an externally unconstrained monopoly to create valid law. Whatever comes out of the democratic procedure of unanimous collective choice making on the foundational constitutional stage is-independently of its substantive normative content - to be treated as legitimate law and only that. Contrary to this view, for typical ,natural law “ approaches content that violates certain substantive natural law demands cannot be rendered law-not even by the unanimous agreement of all. ${ }^{12}$ When Buchanan rejects the latter view this is in the spirit of Hartian legal positivism which insists on the conceptual distinction between law that is from law as ought to be. ${ }^{13}$ At the same time Buchanan and Tullock, in the spirit of natural law theory,

Footnote 7 (continued)

pretation of Hobbes. I will leave the latter possibility out of account since my aims are not Hobbes exegetical. They rather focus on the impact of Hobbesian logic on modern economics as characterized in Robbins (1935).

${ }^{8}$ We owe to one of the foes of instrumental rationality the perhaps best characterization of instrumental reason: "Reason is calculative, it can assess truths of fact and mathematical relations but nothing more. In the realm of practice therefore it can speak only of means. About ends it must be silent. Reason cannot even, as Descartes believed, refute skepticism; and hence a central achievement of reason according to Pascal, is to recognize that our beliefs are ultimately founded on nature, custom and habit." (MacIntyre, 2013, p. 54). What this implies in a technological and behaviorally informed interpretation of so-called normative economics is spelled out in detail in (Albert, 2015).

9 If they are part of the body politic and reject a previously enacted rule that could not have been enacted without their assent (omission of veto) they do not respect the authority of the basic constitutional procedure. If they are willing to go against the veto of at least one other individual this also would be a flagrant breach of the basic constitutional rule of order creation in unanimous agreement. "Unless the parties agree to participate in this way in the ultimate constitutional debate and to search for the required compromises needed to attain general agreement, no real constitution can be made. An imposed constitution that embodies the coerced agreement of some members of the social group is a wholly different institution from that which we propose to examine in this book." (Buchanan and Tullock, 1962/1999, vol. 3, p.15).

10 The body politic has a kind of Hobbesian natural "right" to reach any agreement since in Buchanan's scheme there cannot be substantive (knowledge of) obligations that could invalidate the agreement of all.

11 The unanimity constraint would not respect the separateness of all persons in all regards if any number could go ahead on some issue without having to ask all others. As Buchanan states in "Politics Without Romance" the " 'political exchange' necessarily involves all members of the relevant community rather than the two trading partners that characterize economic exchange" (1999b, vol. 1, p. 50, italics Buchanan's). Michael C. Munger is one of the few adherents of Buchanan who are fully aware of the importance of this universalist aspect (Munger, 2017, p. 372); see for a more extensive treatment of the foundational role of unanimity in constituting markets (Brennan Kliemt, 2019b).

12 A community of individuals who agree unanimously to kill themselves at a certain time in a certain way can be doing wrong for the natural law theorist but not for Buchanan. In an interpretation of Hobbes in medieval terms there would be a natural obligation to preserve oneself. Since my primary purposes is not Hobbes exegesis I dismiss this competing interpretation of Hobbes here out of hand and, as Buchanan, rely on a Spinozist account of Hobbes.

13 In the index volume of Buchanan's collected works there are merely two entries on "legal positivism" Buchanan (2002, vol. 20, p.113). 
seek to restrict the power to enact law procedurally on the ultimate constitutional level by the "internal" requirement of "unanimous agreement of all in the shadow of universal veto power":

In discussing an original constitution or improvements in an existing constitution, we shall adopt conceptual unanimity as a criterion ... First, only by this procedure can we avoid making interpersonal comparisons among separate individuals. Secondly, in discussing decision rules, we get into the familiar infinite regress if we adopt particular rules for adopting rules. To avoid this, we turn to the unanimity rule, since it is clear that if all members of a social group desire something done that is within their power, action will be taken regardless of the decision rule in operation. (1962/1999, vol. 3, p.15).

That unanimity concerning content is to be regarded as sufficient for bestowing the status of positive law on the basic constitution seems plausible. However, the tenet that content can become positive law only if the conceptual unanimity proviso is fulfilled, is highly implausible - in particular on the sub-constitutional level. In view of this Buchanan and Tullock allow on the constitutional level for what Hart called power conferring rules that delegate legal powers to citizens, the legislature and courts. Yet, the scope and limits of this practically necessary delegation must be interpreted with care, since

it is precisely at this level that profound and ultimately dangerous confusion emerges about the role of the state in making constitutional law and in modifying the whole set of legal arrangements, including the assignment of individuals' rights and claims. In its most blatant form this confusion emerges in the form of legal positivism, which states that 'the law' is what the state determines it to be and that individual rights are, and must be defined, by the state and, as a consequence are necessarily dependent on the state. (Buchanan, 2001a, vol.18, p. 176) ${ }^{14}$

In the spirit of the Anglo Saxon rule of law tradition all legal powers- including those of a sub-constitutional state legislature-are to be conceived as bound by constitutional law. In Buchanan's account this constitutional law is positive law whose substantive content is acknowledged to be agreement- rather than knowledge-based. ${ }^{15}$ As a criterion of validity a constitution that meets the test of "conceptual unanimity among all parties in the political group" (Buchanan \& Tullock, 1962/1999, vol. 3, p.7) is meant to serve the same functions as knowledge of what the law "ought to be" in natural law theories. ${ }^{16}$

\footnotetext{
14 Bertolini (2019) as a legal scholar working in the Leoni-Hayek tradition reconstructs what he calls "Buchanan's rigid legal positivism" as one of the variants of legal positivism that Buchanan himself rejects in this passage. Other than the present paper, Bertolini does not frame Buchanan as a Hartian but rather a Kelsenian legal positivist. He does not sufficiently appreciate the point that Buchanan himself thinks of legislation as being constrained by the principle of conceptual unanimity. Yet, Bertolini's criticism that Buchanan - in this again akin to Kant - does not specify how conceptual unanimity may operate as a constraint in institutional-legal practice, stands.

15 In relativist ethics this carries over to ethics as a whole. For instance, John Mackie (1977) quite in line with Buchanan's views on the foundations of ethics thought of it in terms of ,inventing right and wrong " or as a technological description (Albert, 1985) of mechanisms of intrinsic and extrinsic "moral motivation".

16 Buchanan and Kelsen were convinced that the meta-ethical belief that verdicts of right and wrong in matters practical have an epistemic status equivalent to judgments of right and wrong in theoretical matters would incline "cognitivists" towards imposing their substantive ethical views on others in ways incompatible with the principles of constitutional democracy. This thesis about the effects of a certain meta-ethical stance in Buchanan and Kelsen and the empirical pre-suppositions that could be invoked to make the thesis plausible are beautifully laid out in (Berggren, 2016). The late Norman Barry who was an adherent of Har-
} 


\subsection{Unanimity as basic democratic requirement}

Buchanan's foundational principle of collective choice making under the unanimity constraint fulfills functions of Kelsen's (basic norm) „, Grundnorm “. Since "ought cannot be derived from is", a Grundnorm, thinks Kelsen must be ("hypothetically") presupposed for identifying valid law and what ought to be done according to it. Moreover, the hierarchical structure of the legal order (,,Stufenbau der Rechtsordnung”) renders normative legal validity hereditary (or a matter of pedigree). This bestows unity on the legal order and provides criteria of what is and what is not part of it. ${ }^{17}$

Like Kelsen's basic norm Buchanan's democratic unanimity provides a-substantively unconstrained-,formal “ foundation of legal validity and unity of the legal order by ,authorizing “ all rules as originating from a single constitutional procedure as its unique source. Buchanan is aware that not all law is enacted law. In his (as in Kelsen's) account other sources can be authorized to create valid law. Yet, both Buchanan and Kelsen believe a. that for the sake of determinateness of law there must be single ultimate criterion for what is and what is not part of a legal order and b. that the criterion cannot be merely descriptively identifying what is a legal norm.

To the extent that democratic bodies did not impose substantive restrictions on the powers they transferred to courts the latter may decide without any substantive restrictions. ${ }^{18}$ However, to the extent that the power conferring rules are determinate in not conferring certain powers the courts have no law-making authority at all. For Buchanan, courts are bound to play by the "law as is" and according to the power conferring and restraining rules that the law that is, as a matter of fact provides. ${ }^{19}$

If courts do not follow a mode of interpretation in which finding has priority over making law the authority of the basic procedure and the control that the sovereign exerts over the constitution are undermined. The determinateness of law which is necessary to allow for definite commitments and compromises on the level of rule choice becomes endangered

\footnotetext{
Footnote 16 (continued)

tian legal positivism also framed the role of conceptual unanimity in Buchanan's approach as equivalent to the role of natural law in other responses to the Hobbesian non-cognitivist (relativist) challenge; see Barry (1984).

17 To account for the unity of the legal order — „die Einheit der Rechtsordnung “ — was one of Kelsen's (1934/2000) central theoretical concerns. For Buchanan this unity is practically important because he intends to protect the authority of the democratic sovereign against intrusions by the legislature and the judiciary; see e.g. (2001a, vol. 18, pp. 176-177; 2001b, vol. 18, pp. 317-341).

18 Buchanan would, of course, admit that in the realm in which courts have discretionary powers they do not find but make law. Yet, for him the courts (and also members of the legislature) must be aware that the constitution confers merely limited powers on them. They first have to find in the spirit of truth seeking which constitutional rules have been made in constitutional choices of rules and then make their choices as within constitutional rule choices.

19 That lawyers sometime seem to believe that there cannot be any legal limits to legal powers of courts seems due to the distorted picture that arises from focusing exclusively on cases that do in fact go to court. However, in this they behave like a management theorist would if she were to form a theory of entrepreneurial behavior on the basis of firms that went bankrupt. Buchanan seems at least implicitly of the opinion that whenever courts have interpretative room they should frame their task as one of "finding" solutions in the light of sub-constitutionally enacted law and precedents. For Buchanan "legitimate legal interpretation" is always restrained by what courts "found" as 'being the constitution that is'.
} 
(a much-neglected effect of the ever-present proclivity to interpret law "creatively" in the name of "ethics" and other considerations deemed "higher" than the constitution). ${ }^{20}$

The structural similarities between Kelsen's and Buchanan's basic conceptions include some of the more precarious aspects of Kelsen's legal positivism, as well. In particular, Kelsen thought of the Grundnorm as a quasi-transcendental ,pre-supposition“ necessary to constitute law as an object of his ,pure“ theory of law. Similarly, Buchanan conceives of conceptual unanimity as ultimately unavoidable assumption (a ,relatively absolute absolute ") of a theory of legitimate order in a constitutional democracy.

To accept the authority of factually prevailing unanimity as sufficient for fixing legitimate law seems indeed a kind of unavoidable consequence of our modern understanding of respect for individual and collective/democratic autonomy. It is from a modern point of view hard to imagine what could meaningfully be objected against real agreement of virtually all individuals (including unanimous agreement to commit suicide). However, whether or not rules could "conceivably" be the (direct) result of unanimity, can hardly be decisive for the factual status of law: If the constitutional rules that do not meet the test of conceptual unanimity do not automatically lose their factual influence on the real world-which, to put it euphemistically, is empirically unlikely - it becomes unclear what the criterion of conceptual (fictitious) unanimity says about the factual status of those rules as "positive" constitutional law.

The question looms large why real people who as a matter of fact have not agreed should care about what all would conceivably have agreed to under some ideal—contrary to fact-conditions. From a philosophical point of view unsurprisingly, in his efforts to justify the relevance of such merely conceivable conditions and uses of his basic procedural norm Buchanan becomes a kind of Kantian, a "Bukantian". 21

\section{Bukantianism}

The requirement of "unanimous agreement in the shadow of universal individual veto power" is normative and-in that sense-reaches beyond "the logical [emphasis added, HK] foundations of constitutional democracy" (Buchanan \& Tullock, 1962/1999, vol. 3, subtitle). It is instructive to take a closer look at Buchanan's efforts to argue for "conceptual unanimity" as a "relatively absolute absolute" with reasons that do not appeal only to him personally. ${ }^{22}$

\footnotetext{
${ }^{20}$ Even those who stick to the distinction between factual prevalence of norms as law and their normative validity accept today that rule of law is not only about rules. Some role must and can be assigned to principles (that provide much less stringent guidance than specified rules) within a positivist approach to explicating the concept of law. As far as such a broadened concept is concerned one might suggest that courts will check whether positive law - including "positive principles" - meet the "conceptual unanimity" test; see again (Coleman, 1985, chap.1).

21 See on this also (Kliemt, 2011) and for the presumably better alternative term "Buchantianism" suggested by the native speaker in (Brennan and Kliemt, 2019a).

22 The following interpretation does not claim that Buchanan succeeds overall. Relying on "conceptual unanimity" he succeeds "only" in presenting a variant of contractarianism that is superior to the prevailing variants that are based on "mutual advantage" rather than "mutual agreement". It will be shown, first, that Buchanan's model expresses the ideals of adherents of constitutional democracy strikingly well and, second, that it, however, does not provide compelling reasons why those who do not share the ideals of inclusive constitutional democracy to start with should convert to it.
} 


\subsection{Unanimity as expressive of political Kantianism}

Where Kant uses an ideal "form " of imperatives and "conceivable universalizability" of "maxims of the will" Buchanan introduces an ideal "procedure" and requires conceptual unanimity or unanimous agreement under it as a test. The Kantian abstract principle of inter-personal respect of never ${ }^{23}$ intentionally using another person only as "a means to an end ${ }^{\text {"24 }}$ is expressed in procedural terms by the veto condition; that is, to the extent that all affected individuals could have used their-collectively guaranteed-veto but omitted to make use of it none can have been used „only as means“.

Kant's practical philosophy was strongly influenced by his intense reading of Rousseau. In response, Kant seeks to resolve the tension between Rousseau's "general will" and the prevailing "will of all" by testing the maxim of the individual will for its universalizability. What can conceivably be a universal law for all individuals who are endowed with reason cannot use others as mere instruments. ${ }^{25}$

The basic procedure underlying the "foundations of constitutional democracy" provides also a solution for the eternal conflict between individual self-determination and collective co-determination. Rousseau states the problem thus:

'The problem is to find a form of association which will defend and protect with the whole common force the person and goods of each associate, and in which each, while uniting himself with all, may still obey himself alone, and remain as free as before.' This is the fundamental problem of which the Social Contract provides the solution. ((Rousseau, 1762/1923), chap VI, ,The social compact”.)

Buchanan's solution of "unanimous agreement of all in the shadow of universal veto power" starts from collective rather than individual decision making on all matters while building Kantian interpersonal respect into the constitutional procedure itself. From a philosophical point of view this way of reducing the ideal theory of constitutional democracy to its core principle must be counted among the greater-if widely unnoticed-analytical accomplishments of modern political philosophy. For philosophers who focus on ideal theory standards in evaluating real world institutions of "liberal democracies" it can serve as a guiding principle when developing an evaluative metric. ${ }^{26}$

Yet, Buchanan intends to justify his solution with arguments that do not transcend the limits of economic instrumental rationality. Then-if reason is restricted to instrumental rationality-problems arise from the fact that the universality of Buchanan's solution

\footnotetext{
${ }^{23}$ The "never" is meant to imply that nobody should ever be treated as a mere means.

24 It seems significant that Kant is endorsed explicitly and extensively by Buchanan's then Charlottesville colleague Rutledge Vining in an essay solicited by UNESCO as a kind of authoritative overview over ,Economics in the United States of America "; see (Vining, 1956, p.19) and also (Dorn, 1987, p.286). An interesting ethical theory account of the relation between unanimity in the shadow of individual veto and Kantian respect can be found in (Davis, 1992) who regrettably seems unaware of Buchanan.

${ }^{25}$ Kant is, of course, loading the dice in favor of his own normative inclinations by relying on a concept of rule-bound rationality that is, in a way, the anti-thesis of the economic model of instrumental rationality as opportunity seeking case-by-case choice making in view of the future causal consequences of each act taken separately; see for more details on the role of the latter concept in Austrian economics, game theory and the works of the Bloomington school (Kliemt, 2017).

${ }^{26}$ Relying on ideal theories is criticized by some economic philosophers, e.g. (Brennan and Pettit, 2005), (Hamlin and Stemplowska, 2012) but accepted by most other philosophers. That in particular adherents of ideal theories of democracy fail to understand that relying on Buchanan's approach would improve their own theories has presumably ideological reasons.
} 
depends on normative premises that are not universally but only contingently fulfilled: the solution presupposes that (a.) the community of individuals is exogenously "given" and (b.) has a monopoly on all legitimate choices. If (a.) were not fulfilled, then who has a vote ("voice") and would be respected by the community through granting her or him a veto might not include all members of the relevant "demos". If (b.) were not fulfilled, then there could exist dimensions along which individuals would not be guaranteed a veto by the community and therefore could be used by it as means to its ends. ${ }^{27}$

The ("ultimate") collective monopoly on all legitimate choice making in a pre-defined community along with the universal individual veto assures that neither the collectivity as a whole nor any of its members (no member is entitled to act on her own) can ever act in a way that uses a member of the community only as a means. ${ }^{28}$ Buchanan unites the Weberian state monopoly of the use of violence with the Kantian restriction of that political monopoly to what respects the autonomy of each and every member of the body politic. ${ }^{29}$

As indicated already, if real consent ever would fulfill the demanding conditions of Buchanan's basic norm of "democratic unanimity in the shadow of universal individual veto power" this would be the end of the argument. In this sense Buchanan succeeds as an ideal theory philosopher in establishing the ideal. Yet, since real unanimity will as a matter of fact never be forthcoming Buchanan has to invoke not only real but also merely conceptual unanimity if he wants to say something about non-ideal states of the world. He has to come up with an argument why his fiction is relevant for real actors. Again he does so in a philosophically interesting way but on that way violates the self-imposed "legal positivist and ethical relativist" constraints.

\subsection{Conceptual unanimity - Bukantianism's clay feet}

Even if those gathered around the philosophical campfire or at the ,round table of deliberative democracy " (or whatever is the philosophical fashion of the day) may in fact all concur in their discussion that agreement is conceivable, the conceivability claim itself remains a mere theoretical (,logical ") conclusion and not the consent itself. The conception is not its ("conceived") object (as an image is not the object it represents). That real people are used as ,mere means “ in real politics is not prevented by imagining that they would assent to what happens to them under ideal (i.e. non-real) conditions.

Moreover, if $\mathrm{A}$ has apples $\mathrm{a}$ and $\mathrm{B}$ has bananas $\mathrm{b}$, A prefers having $\mathrm{b}$ to having $\mathrm{a}$ and $\mathrm{B}$ prefers having a to having $\mathrm{b}$, then it can be predicted that presumably $\mathrm{A}$ and $\mathrm{B}$ would agree that $\mathrm{a}$ and $\mathrm{b}$ switch places. Yet the prediction that this would happen is not the agreement to swap a with b. Neither is it an exchange if somebody else, say, $\mathrm{C}$ would switch the places of $\mathrm{a}$ and $\mathrm{b}$ since it would make both better off without the agreement of $\mathrm{A}$ and $\mathrm{B}$.

To prevent using real persons as means they must actually be asked. The conceivability of agreement generates merely the empirical hypothesis that they might agree. It has none

\footnotetext{
27 That the conditions (a.) and (b.) would be of crucial importance if Buchanan's basic requirement of conceptual unanimity would be used as an interpretative principle by a court seems obvious.

28 Since the veto is bi-universal-covering all individuals and all actions - legitimate action could have occurred only under the condition that each individual has omitted to veto it. Therefore, none can have been used as a mere means.

29 Quite in line with the maxim that ,there is no free lunch “, the universal right to veto everything comes along with the universal obligation to omit any act unless authorized by unanimous agreement.
} 
of the normative ethical force that we commonsensically and legally ascribe to real agreement and the "volenti non fit iniuria" responsibility ascription that supports it. ${ }^{30}$

Buchanan himself acknowledges this in his central programmatic paper ,What should economists do? " (1999a, vol.1). There he insists that economists should restrict themselves to identifying possible Pareto improvements. Only if the proposals they make are universally advantageous can agreement-seeking political economists as participants of political interaction hope to find among the rational actors whom they address universal agreement (rather than merely universal advantage as diagnosed from an objective point of view). ${ }^{31}$ Even if the suggestions of constitutional political economy are to the mutual advantage of all members of the community this is in the eyes of Buchanan not sufficient to justify implementation of the suggestions. To legitimately implement them, all suggestions have to be ratified by agreement. ${ }^{32}$

Buchanan's precedingly sketched justification of what constitutional economists should do is a fine piece of integrated practical ethics. It coherently combines demands on participants of the practices of constitutional democracy with demands on participants of constitutional economics within a constitutional democracy. Yet, whatever such coherent constitutional economics proposes it cannot be expected that its own criteria of legitimate implementation be actually fulfilled. ${ }^{33}$ Real unanimous agreement in a Great Society does not exist. ${ }^{34}$ Neither is there real universal agreement that fictitious, merely conceivable agreement should be used as a relevant criterion. Moreover, if we take the Kantianism in Buchanan's "pure theory of constitutional democracy" as seriously as the emphasis on universal veto-power suggests, approximations in terms of supermajority requirements below unanimity will not do.

As a final line of defense, it might be pointed out that in a Great Society no theory whatsoever will generate real unanimous approval of its proposals. If no theory can generate real unanimous agreement, we might as well assess theories according to their comparative merits along other dimensions, or so the argument might run. Yet, precisely because Buchanan-type constitutional economics is honestly contractarian and therefore takes agreement (other than e.g. Rawls' merely metaphorical contractarianism with its focus on mutual advantage ${ }^{35}$ ) as foundational category seriously, Buchanan-type constitutional economics cannot take this way out.

\footnotetext{
30 The time-honored principle of ,,volenti non fit iniuria “ expresses the "liberal” assumption that — absent fraud, violence, manipulation etc. - autonomous persons cannot wrong themselves.

31 Alluding to the quasi-Kantian distinction between an objective and a participant's attitude in (Strawson, 1962).

32 Though universal advantage and universal agreement are routinely mixed up by present day contractarians this is systematically misleading and, in that sense, illegitimate. It is one of the great merits of Buchanan that he does not join that crowd but basically sticks - despite occasional detours - to the foundational role of agreement as such. In his excellent recent account of Buchanan's fundamental methodological article Sugden, (2018) downplays agreement in favor of advantage to rescue his Bukantian claim to be a contractarian despite his declared ethical non-cognitivism.

33 A point also made in (Voigt, 1996, pp. 157-183).

34 Jeremy Bentham's (1843) "the demand for a right is no more that right than hunger is bread" is a kind of "bridge principle" in the sense of H. Albert (1985), too. It expresses that "legal ought presupposes legal "is"'. Other than natural law theories assume, a legal demand can carry the normative force of a legal ought only if it refers to pre-existing factual social behavior expressive of that demand already. This requirement is comparable to "ought presupposes can" which itself is seen as bridging the "gap between is and ought" in ways compliant with the Humean verdict against deriving prescriptive conclusions from exclusively descriptive premises.

35 In Rawls' classical words: "Society is a cooperative venture for mutual advantage" (Rawls, 1985). Rawls thereby hijacks the classical agreement-based notion of "contractarianism" by his advantage-based concept.
} 


\section{Conclusion}

For Buchanan the basic constitutional conventions of constitutional democracy derive legitimacy from the authority of agreement rather than the authority of knowledge. To keep fully in line with this in his normative theory he would have to restrain himself to proposing a procedure compliant with democratic unanimity in the shadow of universal individual veto power that he would expect to be self-referentially accepted in real universal agreement. The "rest" would be "over to the citizens" whose real agreement to and under the constraints of the basic procedure would legitimize specific constitutional conventions as positive law. As an economic theorist Buchanan would have to remain silent on the content of such agreement-based constitutional law. Yet, Buchanan wants to go beyond the procedural proposal and to say something as a constitutional economic theorist about substantive constitutional rules. ${ }^{36}$

For this he brings in the fiction of conceptual unanimity rather than real unanimity. That all sorts of fictions have had high currency in economics - in particular in general equilibrium analysis and game equilibrium models-is perhaps an excuse but no justification for relying on fictions in constitutional economics.

In response Buchanan could have taken openly to philosophical methods of justification and could have relied on a search for Rawlsian reflective equilibrium. Within such a philosophical enterprise "unanimous agreement in a democratic community" could have served as a characterization of a "democratic original position" in which representative rational choice makers act as avatars of the citizens. As in the extended Rawlsian search for reflective equilibrium in his Theory of Justice (1971) this could have been embedded into an account of the factually prevailing practices of Western Great Societies and the basic intuitions of citizens concerning how specific problems should be solved according to the practices in which they do as a matter of historical fact participate. Buchanan's communitarian contractarian construction could then have been based on a democratic original position embodied in real political practices and opinions to fully show its metal as the important contribution to twentieth century political philosophy that it without doubt is. ${ }^{37}$

The empirical hypothesis that complicated narratives are potentially doing more harm than good when it comes to stabilizing Great Societies is all but outlandish, though. ${ }^{38}$ For instance, the description of something as if it were the outcome of universal agreement makes it look more harmless than it is. As a matter of fact, it is imposed on individuals. The application of fundamental coercion is merely camouflaged. Describing it as if of the agreement type makes it as a matter of fact harder to distinguish between acceptable and non-acceptable coercion.

In view of such real risks the nicest thing that can safely be said about ideal theory approaches of theoretical economics, practical philosophy etc. might well be that they are

\footnotetext{
36 Of course, as a citizen he would be free to do so. However, Buchanan intends to speak as a constitutional economist with the authority of disciplinary knowledge.

37 I personally think of Buchanan's democratic contractarianism as the strongest variant of political philosophical contractarianism. Yet, despite their great achievements and considerable intellectual charms ideal contractarian theories seem to me ultimately as inacceptable as other ideal theories of pure economics that are non-approximable in generic parameter intervals by empirically testable theories; see on approximable and non-approximable idealizations (M. Albert and Kliemt 2017).

38 On reflective equilibrium search see (Daniels, 1979) and (Hahn, 2000).
} 
practically impotent. In the latter case we could enjoy intoxication by beautiful constructions without any hangover at the horizon. However, thinking of the Keynesian scribblers (among which today Keynes himself would have to be counted), we must be aware that theoretical fictions of the past can influence present opinion and often for worse rather than better. Since it is "on opinion only that government is founded" (Hume, 1985, 32), I tend to believe that it may be better to restrict the authority of constitutional political economy to the role of witnessing facts including those that are relevant to opinion formation.

For such and some more theoretical reasons at least I remain skeptical that engaging elaborate philosophical theories will do much good. ${ }^{39}$ In the end empirical Public Choice theory without the normative underpinnings of normative constitutional political economy will presumably serve technological purposes of economic constitutional policy analysis best. In particular the purpose of finding means towards the end of protecting liberty and its priority in a constitutional democracy may be served better by an empirical understanding of how constitutional democracies actually work than by any contractarian fictions. Still, since political reflection as a matter of fact will not stop as long as constitutional democracies exist we can as well enjoy Buchanan's fascinating theories beyond his $100^{\text {th }}$ anniversary and hope, as he certainly did, that this will make the world a better place by shaping our opinions in ways supporting the rule of law.

Acknowledgements I am grateful for the excellent criticisms and constructive comments of two referees. Exchanges with Max Albert, Michael Baurmann, Niklas Berggren, Daniele Bertolini, Geoffrey Brennan and Horacio Spector concerning the topics of this paper led to several improvements, too; of course, the conventional disclaimer applies.

Funding Open Access funding enabled and organized by Projekt DEAL.

Open Access This article is licensed under a Creative Commons Attribution 4.0 International License, which permits use, sharing, adaptation, distribution and reproduction in any medium or format, as long as you give appropriate credit to the original author(s) and the source, provide a link to the Creative Commons licence, and indicate if changes were made. The images or other third party material in this article are included in the article's Creative Commons licence, unless indicated otherwise in a credit line to the material. If material is not included in the article's Creative Commons licence and your intended use is not permitted by statutory regulation or exceeds the permitted use, you will need to obtain permission directly from the copyright holder. To view a copy of this licence, visit http://creativecommons.org/licenses/by/4.0/.

\section{References}

Albert, H. (1985). Treatise on critical reason. Princeton University Press.

Albert, M. (2015): The behavioral challenge to normative economics, In: Müller, C. and Otter, N. (ed.), Behavioral Economics und Wirtschaftspolitik. Schriften zu Ordnungsfragen der Wirtschaft Bd. 100, (pp. 3-28), Stuttgart: Lucius \& Lucius.

Albert, M. and Kliemt, H. (2017). Infinite idealizations and approximate explanations in economics (MAGKS Papers on Economics). Philipps-Universität Marburg, Faculty of Business Administration and Economics, Department of Economics (Volkswirtschaftliche Abteilung). https://EconPapers. repec.org/RePEc:mar:magkse: 201726

Barry, N. P. (1984). Unanimity, agreement and liberalism. A critique of James Buchanan's social philosophy. Political Theory, 12(4), 579-596.

\footnotetext{
39 As the reader will certainly have noted, there is a structural similarity of this complaint with the one Buchanan and Kelsen offer concerning the effects of cognitivist meta-ethical positions; see for the latter again (Berggren, 2016).
} 
Bentham, J. (1843). Anarchical fallacies. In Bowring, J. (ed.) The collected works of Jeremy Bentham (Vol. 2, Art. II.3) Edinburgh: William Tait. https://oll.libertyfund.org/title/bowring-the-works-of-jeremybentham-vol-2\#lf0872-02_head_411.

Berggren, N. (2016). Does belief in objective morality lead to coercion? An analysis of the arguments of Kelsen and Buchanan”. Review of Austrian Economics, 29(3), 315-326.

Bertolini, D. (2019). Constitutionalizing Leviathan: A critique of Buchanan's conception of lawmaking. Homo Oeconomicus, 36(1), 41-69.

Brennan, G. and Kliemt, H. (2019a). Kantianism and political institutions. In Congleton, R.D., Grofman. B. N., Voigt, St. (eds.). The Oxford Handbook of Public Choice, (Vol. 1, pp. 796-813) Oxford / New York / Toronto / Sydney / Paris / Frankfurt: Oxford Handbooks.

Brennan, G., \& Kliemt, H. (2019). The constitution of markets. In R. Wagner (Ed.), James M. Buchanan: A theorist of political economy and social philosophy (pp. 807-838). London New York: Palgrave Macmillan.

Brennan, G. and Pettit, P. (2005) The feasibility issue. In: Jackson, F. and Smith, M (eds.) The Oxford Handbook of Contemporary Philosophy, Oxford University Press, (pp. 258-279)

Buchanan, J. M. (1999a). What should economists do? In Brennan, G. Kliemt, H. and Tollison, R.D. (eds), The logical foundations of constitutional liberty. The collected works of James M. Buchanan (Vol. 1, pp. 28-42), Indianapolis: Liberty Fund.

Buchanan, J. M. (1999b). Politics without romance. In Brennan, G. Kliemt, H. and Tollison, R.D. (eds), The logical foundations of constitutional liberty. The collected works of James M. Buchanan (Vol. 1, pp. 45-59), Indianapolis: Liberty Fund.

Buchanan, J. M. (1975/2000). The limits of liberty. The collected works of James M. Buchanan (Vol. 7), (Kliemt, H., ed.). Indianapolis: Liberty Fund.

Buchanan, J. M. (2001a). Criteria for a free society. Definition, diagnosis, and prescription. In Kliemt, H. (ed.), Federalism and the law The collected works of James M. Buchanan (Vol. 18, pp. 172184), Indianapolis: Liberty Fund.

Buchanan, J. M. (2001b). Cultural evolution and institutional reform. In Kliemt, H. (ed.), Federalism and the law The collected works of James M. Buchanan (Vol. 18, pp. 311-323), Indianapolis: Liberty Fund.

Buchanan, J. M. (2002). Indexes. The collected works of James M. Buchanan (Vol. 20), Indianapolis: Liberty Fund.

Buchanan, J. M. and Tullock, G. (1962/1999). The calculus of consent. The collected works of James M. Buchanan (Vol. 3), (Tollison, R.D., ed.), Indianapolis: Liberty Fund.

Coleman, J. L. (1985). Markets, morals and the law. Cambridge University Press.

Daniels, N. (1979). Wide reflective equilibrium and theory acceptance in ethics. The Journal of Philosophy, LXXV, I(1), 265-282.

Davis, M. (1992). The moral legislature: Contractualism without an archimedean point. Ethics, 102(2), $303-318$

Dorn, J. A. (1987). Government, the economy and the constitution. Cato Journal, 7(2), 283-303.

Green, L. (2018). Legal Positivism. In E. N. Zalta (ed.), The stanford encyclopedia of philosophy (Spring 2018.). Metaphysics Research Lab, Stanford University. https://plato.stanford.edu/archives/ spr2018/entries/legal-positivism/

Hahn, S. (2000). Überlegungsgleichgewicht(e). Prüfung einer Rechtfertigungsmetapher. Freibrug i.Br.: Karl Alber.

Hamlin, A., \& Stemplowska, Z. (2012). Theory, ideal theory and the theory of ideals. Political Studies Review, 10(1), 48-62.

Hart, H. L. A. (1961). The concept of law. Clarendon Press.

Hobbes, T. (1651/1968). Leviathan. (MacPherson, C.B. ed.), Harmondsworth: Penguin.

Hume, D. (1985). Of the first principles of government. In E. F. Miller (Ed.), Essays, moral, political and literary (pp. 32-36). Indianapolis: Liberty Fund.

Kant, I. (1991). Political writings. The metaphysics of morals. (Reiss, H.D. ed.), Oxford, Oxford University Press.

Kelsen, H. (1934/2000). Reine Rechtslehre (2.überarb.Aufl.). Wien: Verlag Österreich.

Kliemt, H. (1994). The calculus of consent after thirty years. Public Choice, 79(3-4), 341-353.

Kliemt, H. (2011). Bukantianism-Buchanan's philosophical economics. Journal of Economic Behavior \& Organization, 80(2), 275-279.

Kliemt, H. (2017). ABC - Austria, Bloomington, Chicago: Political economy the Ostrom way. In: Aligica, P. D., Lewis, P, Storr, V. H. (eds), The Austrian and Bloomington Schools of political economy. Advances in Austrian economics, 22:15-47.

MacIntyre, A. (2013). After virtue (Reprint.). London: Bloomsbury Academic. 
Mackie, J. L. (1977). Ethics, inventing right and wrong. Harmondsworth: Penguin.

Munger, M. C. (2017). On the origins and goals of Public Choice. The Independent Review, 22(3), $359-382$.

Rawls, J. (1971). A theory of justice. Oxford University Press.

Rawls, J. (1985). Justice as fairness: Political not metaphysical. Philosophy \& Public Affairs, 14(3), 223-251.

Robbins, L. (1935). An essay on the nature and significance of economic science. London: Macmillan.

Rousseau, J.-J. (1762/1923). The social contract and discourses by Jean-Jacques Rousseau. (Cole, G.D.H. ed.) London and Toronto: J.M. Dent and Sons. https://oll.libertyfund.org/titles/rousseau-the-socialcontract-and-discourses\#lf0132_label_065

Spinoza, B. de. (1670/1951). A theologico-political treatise. A political treatise. (Elwes, R.H.M. transl.), New York: Dover.

Strawson, P. F. (1962). Freedom and resentment. Proceedings of the British Academy, 48, 187-211.

Sugden, R. (2018). What should economists do now? In R. Wagner (Ed.), James M. Buchanan: A theorist of political economy and social philosophy (pp. 13-37). London New York: Palgrave Macmillan.

Vining, R. (1956). Economics in the United States of America. A review and interpretation of research. UNESCO.

Voigt, S. (1996). Die konstitutionelle Ökonomik als Herausforderung für die Theorie der Wirtschaftspolitik - zugleich eine Skizze zur Weiterentwicklung einer ökonomischen Theorie der Verfassung. In I. Pies \& M. Leschke (Eds.), James Buchanans konstitutionelle Ökonomik (pp. 157-183). Tübingen: J.C.B. Mohr.

Publisher's Note Springer Nature remains neutral with regard to jurisdictional claims in published maps and institutional affiliations. 